\title{
TAXing VIRTUal Worlds: Can the IRS Pawn You?
}

\author{
By Eric G. Roscoe \\ Volume XII - Fall 2011
}

\begin{abstract}
This article examines whether the transactions between players of online virtual world games can give rise to taxable events. It also compares two earlier articles on the same topic, and argues that the intellectually pure conclusion is that every transaction in virtual worlds creates a taxable event. While the article concludes that the events are taxable, it argues that similar to frequent flier miles, the income from a virtual transaction should not be taxed until it is converted to real world currency. The IRS has implemented Section 6050W designed to require companies like PayPal to report the transactions of their biggest customers. The rules are applicable to virtual world players, but do not perform a sufficient function of ensuring reporting compliance because the number of transactions required to trigger a report are far too high.
\end{abstract}




\title{
TAXING VIRTUAL WorLdS: Can the IRS PWN You?
}

\author{
By Eric G. Roscoe
}

Volume XII - Fall 2011

It has been a long day for Terry. He spent the morning making and selling tee-shirts in a small shop on the edge of town. In the afternoon he had a job interview with AT\&T, went to a shareholders meeting for Air France-KLM, and then spent the evening working as a security guard for the local night club. Terry never got the job with AT\&T, but he made 2000 Lindens selling shirts as a licensed distributor for American Apparel and 300 Lindens for his security work. Once Terry's shift at the club was over, he logged off of his computer and went to bed. Terry was working in a virtual world known as Second Life. The Internal Revenue Service (IRS) wants to know whether Terry and millions of other players or workers are taxable on their earnings within this world, and more importantly, how. ${ }^{1}$

This paper aims to answer one question: How can the IRS administer a program that taxes income from activities in the virtual world? Many articles have examined the nature of virtual worlds and asked whether transactions generated within the virtual world should be taxed as if there was a realization and recognition event giving rise to taxable income. ${ }^{2}$ This paper argues that the deeper one looks into virtual worlds, especially those like Second Life, the harder it becomes to apply traditional tax rules. However, there is no need to look into what happens

\footnotetext{
1 National Taxpayer AdVocate, 2008 AnnUal Report to CONGRess 2104 (Vol. 1, 2008) available at http://www.irs.gov/pub/irs-utl/08_tas_arc_intro_toc_msp.pdf.

${ }^{2}$ Compare Bryan T. Camp, The Play's the Thing: A Theory of Taxing Virtual Worlds, 59 Hastings L.J. 1, 69 (2007) (arguing that the in-world play does not involve any traditional realization events, but just imputed income that is recognized at the time it is exchanged), with Leandra Lederman, "Stranger Than Fiction": Taxing Virtual Worlds, 82 NYU L. REV. 1620 (2007) (arguing that the type of game play should decide whether in-world transactions are realization events).
} 
within the game. Tax should be applied only at the time actual cash is pulled out through PayPal, Google Checkout and similar sales sites.

The first part of this paper explains the way income is generated within virtual worlds with a focus on Second Life. Part II provides an overview of literature that examines when revenue generating game play should be taxed. There are two camps; one argues that simple trades and sales within the game are recognition events for tax purposes. ${ }^{3}$ The other camp argues that only at the time real cash is pulled from the virtual world should there be recognition. ${ }^{4}$ Part III uses gambling as an example of how one author's analysis draws the correct conclusion about current tax law. Transactions in Second Life are taxable because the currency of the game is readily exchangeable for real U.S. dollars. Part IV argues that in spite of the fact that taxable income is being generated, the IRS should not delve too deep into the virtual world; they should sit on the border and tax transactions as they cross over in the form of real world currency. This is best achieved through reporting requirements imposed on transaction facilitating websites like Google Checkout and PayPal. The IRS can ensure that those working in the virtual world are taxed while those playing remain unaffected. Part V concludes with an overview of how this year's tax changes will help to ensure compliance of virtual world participants.

\section{Virtual Worlds: So I'm done with work and I go home to play a game in which I work?}

Role playing games have been popular on the Internet since the early 1990s, but with the ability to render actual interactive worlds that look much like our own, the number of players has

\footnotetext{
${ }^{3}$ Lederman, supra note 2, at 1667.

${ }^{4}$ Camp, supra note 2, at 66.
} 
expanded drastically..$^{5}$ Some of these games are just that, games. The player engages in battles and missions, earning rewards in the form of virtual gold or skills, which allows the player to engage in more complex and interesting missions. ${ }^{6}$ Within these worlds the game designers have largely taken a backseat to the progress of the players. The game designers may design missions and place prizes within the world, but they do not decide any particular linear progression for the player. Over time, the large amount of options within these games creates an artificial scarcity. The fact that one player was ranked higher than another, or that one player had an item that the game designers had not made many of, gave the individual player and item value. Rather than spending the time leveling up one's own character, a player could buy a character with advanced skills through eBay. $^{7}$

These virtual worlds have created real world value in the hundreds of millions of dollars. ${ }^{8}$ A space station in the virtual world of Entropia sold for $\$ 100,000$ in 2004. That same space station sold just last year for the virtual currency equivalent of $\$ 300,000 .{ }^{9}$ To put it into perspective, Edward Castronova, an economist, examined just one virtual world and calculated its gross national product to equal $\$ 2,266$ per person. ${ }^{10}$ The average player generated an income of $\$ 3.34$ per hour.

5 Parks Associates, Online Gaming Revenues to Triple by 2009 (Dec. 14, 2005) available at http://www.parksassociates.com/press/press_releases/2005/gaming-1.html (predicting a 2009 revenue of $\$ 3.5$ billion in the U.S. alone).

${ }_{7}^{6}$ Camp, supra note 2, at 5 .

7 See generally WARCRAFTLOOT, http://www.warcraftloot.net/buy-accounts/wow (last visited Feb. 9, 2010) (marketing its service by asking who wants to spend weeks killing sickly plains elk?).

${ }^{8}$ Robert Hof, Second Life's First Millionaire, Bloomberg Businessweek (Nov. 26, 2006), available at http://www. businessweek.com/the thread/techbeat/archives/2006/11/second_lifes_first_millionaire.html (Anshe Chung is the first millionaire in Second Life thanks in part to her huge virtual world holdings).

${ }^{9}$ OnlineMassivelyMultiplayer.com, Entropia Universe Crystal Palace Space Station in Planet Calypso Sells for $\$ 330,000$, http://www.onlinemassivelymultiplayer.com/mmo-news/entropia-universe-crystal-palace-space-stationin-planet-calypso-sells-for-330000/ (last visited Feb. 9, 2011).

${ }^{10}$ See Edward Castronova, Virtual Worlds: A First-Hand Account of Market and Society on the Cyberian Frontier 33 (CESifo, Working Paper No. 618, Dec. 2001) available at at http:// papers.ssrn.com/abstract=294828 (discussing how this world generated more GNP than Russia). 


\section{A. Second Life is the Ultimate Virtual World}

Second Life is a virtual world that is unique from all the others. The creator of Second Life, Linden Labs, realized that players were not in search of more rules and design, but would prefer to do anything they wanted in the world. ${ }^{11}$ Second Life does not have content that is not created by the users. This means that if a player wants a house for his character, he needs to build one; If a person wants to play a game, someone needs to design the game and insert it into the world; and if a person wants to change the clothes of his character, then he needs to make them. In order to accomplish this, Second Life provides an object editing tool that allows the user to design anything by shaping and coloring small building blocks known as "primitives." Each block has parameters like a Global Positioning System (GPS) coordinate, and when a Linden Lab server reads those parameters, the block is converted into whatever is described, from hair, to a bike pedal, or a house. ${ }^{12}$

Linden Labs added an additional feature that was largely unavailable in other virtual worlds. $^{13}$ It created a currency, the Linden Dollar, and it supported its trade for real U.S. dollars, Euros, and Yen by maintaining an in-world currency exchange. While a basic account is free, the flow of currency within Second Life starts with a paying player. The paying player receives a certain amount of Lindens when he opens his account, followed by a stipend for every week he logs into the world. This is how currency finds its way into the virtual world. ${ }^{14}$ These players then use the currency to buy virtual goods. When a player wants to get cash out of the system, he can go to the LindeX and exchange his Lindens for real world currency. On the other side of

\footnotetext{
${ }^{11}$ See Julian DibBell, Play Money: Or How I Quit My Day Job And Made Millions Trading ViRTual Loot 192 (2006) (discussing how Linden Labs took a different approach than other developers. Instead of reining in the ability of players to shape their world, Linden Labs developed tools to encourage users to build the in-game environment).

12 See SECOND LIFE Wiki, Primitive, http://wiki.secondlife.com/wiki/Primitive (last visited Feb. 20, 2011) (instructing how to shape and join blocks into complex in-world objects).

${ }_{13}^{13}$ See generally, DIBBELL, supra note 11.

${ }^{14}$ SECOND LIFE Wiki, Account, http://wiki.secondlife.com/wiki/Account (last visited Feb. 20, 2011).
} 
the transaction is another player that wants Lindens so he can buy virtual goods. The LindeX makes the exchange easy by transferring the Lindens between player accounts and the real world currency between PayPal accounts. ${ }^{15}$

There are really two ways to make real world money in Second Life. The first is through the designing, selling and trading of virtual goods. The other is through actual paid labor within the virtual world.

\section{The Second Life Marketplace}

Second life has two unique features amongst virtual worlds, ownership and readily exchangeable currency. Whether one really has legal ownership over property in Second Life is a question for property law professors. ${ }^{16}$ The problem is that the property one creates only looks and acts the way it does because Linden Labs provides a service. That service maintains the virtual world that one can access from his home computer. ${ }^{17}$ The real importance to Second Life as a marketplace is that Linden Labs, by granting users intellectual property rights in their self created content, has really guaranteed users that they will not challenge a user who tries to sell or trade content. $^{18}$

\footnotetext{
15 SECOND LIFE Wiki, Buying Lollars, http://wiki.secondlife.com/wiki/Linden_Lab_Official:How_do_I_buy_Linden _dollars_(L\$)_on_the_LindeX (last visited Feb. 20, 2011).

${ }^{16}$ See generally Megan B. Caramore, Help My Intellectual Property is Trapped: Second Life, Conflicting Ownership Claims and the Problem of Access, 15 RICH. J.L. \& TECH. 3 (2008) (discussing how a Terms of Service agreement that grants user's property rights in their creations is really just paying lip service to the concept of ownership, because without the game creators providing the necessary server space and maintenance of the system the property cannot be visualized).

${ }^{17}$ SECOND LIFE, Terms of Service (Dec. 15, 2010), http://secondlife.com/corporate/tos.php (granting property rights, but maintaining the right to cut off the provision of services at any time).

${ }^{18}$ Compare DiBBELL, supra note 11, at 15 (discussing the traditional approach of other role playing game companies to bring suit against players attempting to sell in-game materials), with SECOND LIFE, Terms of Service (Dec. 15, 2010), http://secondlife.com/corporate/tos.php (expressly providing for the sale of in-game content through a marketplace exchange).
} 
Linden Labs actually promotes the sale of content by maintaining a Second Life Marketplace, where users can post clothing, homes, vehicles, gadgets, advertising space, and gardening supplies (all intellectual property). Linden Labs allows a user to purchase these items with real world currency through a credit card or PayPal account, or with Lindens by logging into the user's account. The marketplace functions much like eBay by charging the seller a five percent commission. ${ }^{19}$

Individual users design and sell items for a profit within the virtual world and actually make a real world living by selling second world goods. The Second Life player can not only design his or her own goods, but can also arbitrage the exchange rate. Virtual arbitrage works when the user can purchase Lindens at a lower exchange rate, then purchase a virtual good with Lindens, and is finally able to sell the good for cash at a higher exchange than the Lindens. The successful Second Life salesman is free to cash out his earnings at any time by using the LindeX.

\section{The Second Life Employee}

Another method of making money in Second Life is by providing services and labor. There is an entire service and entertainment industry in Second Life designed to provide any experience that one can imagine. One can go skydiving, waterskiing, car racing, or clubbing. Users offer these activities to other users for a fee of Lindens. ${ }^{20}$ If a particular club becomes popular, the owner of the club can make hundreds of thousands of real world dollars a year off of entry fees.

\footnotetext{
19 Second Life Marketplace, SL Marketplace Fees and Commissions, SECOND LiFE, https://marketplace.secondlife.com/listing guidelines (last visited Feb. 9, 2011).
$\quad C f$ SECOND LIFE Wiki, Linden Lab Official: Wagering Games FAQ, http://wiki.secondlife.com/wiki/Linden_Lab_Official:Wagering_Games_FAQ (last visited Feb 20, 2011) (banning gambling from amongst the services that one can provide. This is due in large part to the fact that online gambling is illegal in the U.S.).
} 
Just like in the real world, these services cannot be performed without employees. Some users actually obtain jobs where another user pays them a small salary of Lindens to perform a certain task. For example, if a nightclub owner has long lines in front of his club at night he might hire a security guard to make sure people do not get out of hand. The security guard would receive a weekly salary of Lindens for his service. ${ }^{21}$

\section{B. The Questions Raised by a Virtual Market}

Second Life creates unique problems when one tries to apply the tax code to transactions generated by the virtual world. There are transactions taking place in two different places and occasionally they crossover on each other. Under the current code, if I sell a piece of virtual property for real world currency, I must realize the sale and recognize any amount of gain over the basis in the property. If I sell my property for in-world currency, Lindens, whether there is a realization and recognition event is less clear. What about the exchange of Lindens for real world currency? Is the Linden just another piece of virtual property or is it a currency in the traditional sense? Finally, the most difficult question revolves around virtual property for virtual property exchanges. In the real world, Cottage Savings Association v. Commissioner ${ }^{22}$ would answer that the realization occurs when the exchanged property is materially different. Should Cottage Savings also apply in the virtual world?

The articles that will be examined in Part II grapple with the very question of recognition. They debate whether recognition can and should occur "in-world" or within the game environment. For the purposes of this article, it is important to examine both sides of the debate,

\footnotetext{
${ }^{21}$ SECOND LIFE Wiki, Getting Linden Dollars FAQ, http://wiki.secondlife.com/wiki/Getting_Linden_Dollars_FAQ (last visited Feb. 20, 2011).

22499 U.S. 554, 560 (1991).
} 
but to also keep in mind a practical concern of whether it is even necessary to examine the inworld transaction.

\section{Realization and Recognition in What World?}

At the forefront of the argument over when taxation should occur are two articles, The Play's the Thing: A Theory of Taxing Virtual Worlds by Bryan Camp and "Stranger Than Fiction": Taxing Virtual Worlds by Leandra Lederman. This section first examines the basic tax concepts of Camp and Lederman, and then looks at whether either of the two approaches really obtains their goal of making taxation of revenue generated within the worlds possible.

\section{A. Tax Principles Analogous to Virtual Worlds}

The threshold question in all tax matters is whether a taxpayer has income. Gross income defined under $\S 61$ is "income from whatever source derived." 23 The Supreme Court has come to interpret $\S 61$ quite broadly so that any accession to wealth is considered to be income. ${ }^{24}$ Just because a taxpayer has gross income, that income will not necessarily be taxed unless certain events occur first.

\section{The Realization and Recognition Principles}

The simple economic definition of income is an increase in a taxpayer's net worth. If a stock increases in value, then the individual has income, but in the tax world there needs to be a disposition event known as realization. ${ }^{25}$ In the event that property is the item being sold, the

\footnotetext{
${ }^{23}$ I.R.C. $\S 61(\mathrm{a})$ (West 2011).

${ }^{24}$ See U.S. v. Kirby Lumber, 284 U.S. 1, 2 (1931) (holding that the relief of debt placed the taxpayer in a better financial position than before the relief).

${ }^{25}$ MARTIN J. MCMAHON ET AL., FEDERAL INCOME TAXATION OF INDIVIDUALs $₫ 3.02$ (2d ed. 2009).
} 
entire amount received is not recognized as income. The amount realized is defined as the sum of money received plus the fair market value of any property received. ${ }^{26}$ Just holding a stock and having it increase in value is not a realization event because there is no money or property received. It is not until a taxpayer disposes of the stock for cash or property that he will have a recognizable loss or gain. ${ }^{27}$ Section 1001 simply defines the recognizable gain or loss as the difference between the amounts realized minus the taxpayer's basis. Basis is the previously taxed assets used to invest in the property.

One of the more important aspects of realization for our purposes is the fact that a property for property exchange is a realization event. The properties exchanged must be materially different, meaning that they embody legally distinct entitlements. ${ }^{28}$ There are few transactions that do not qualify as materially different. As long as the entitlement to the property is not identical then there is a realizable property for property exchange.

\section{Fair Market Value}

In order to determine the value of property in a property for property exchange, the fair market value (FMV) of the property will be used. The code simply defines FMV as "a question of fact, but only in rare and extraordinary cases will property be considered to have no fair market value." 29 The IRS has largely tried to calculate the FMV of all assets no matter how difficult the calculation may appear. ${ }^{30}$ However, the IRS does not value the leisure time of a taxpayer. If a person chooses to forgo working so that he can stay home and care for his kids,

\footnotetext{
${ }^{26}$ I.R.C. $\S 1001($ b) (West 2011).

${ }^{27}$ See Helvering v. Horst, 311 US. 112, 115 (1940) (holding that the right to receive income is not realization until the actual income is paid).

${ }^{28}$ Cottage Sav. Ass'n v. Comm'r of Internal Revenue, 499 U.S. 554, 566 (1991).

${ }^{29}$ Treas. Reg. $\S 1.1001-1($ a) (amended 1960).

${ }^{30}$ MCMAHON ET AL., supra note 25 , at $\$ 29.14$.
} 
one could interpret that taxpayer as valuing caring for his kids more than his salary. If there is value in caring for the kids, then the time could be assigned a personal value. The IRS chooses not to tax leisure time because it is hard to give a market value, it would be impossible to enforce, and it would be perfectly regressive, meaning it would tax for income not earned. ${ }^{31}$

\section{Frequent Flyer Miles}

Frequent flyer miles were a serious dilemma for the IRS, and ultimately they were found to be an item of economic income that the service would not tax. If an individual buys an airline ticket, and he uses his frequent flyer account to obtain airline miles, the miles themselves will be considered a discount or purchase price adjustment for the customer. However, if the individual is flying on a business trip, obtains airline miles at the expense of the business, and then uses those airline miles for personal trips, he is really receiving income in the form of frequent flyer miles.

The general concept would fall within the scope of $\S 61$ "gross income," because it is an accession to wealth. The calculation would not be terribly difficult to achieve; the value of the frequent flyer miles would be included in income at the time it was redeemed for a leisure trip, and the airline could provide the relevant data through a reporting system. ${ }^{32}$ The IRS initially issued a memorandum stating that a taxpayer, permitted by his or her employer to keep the earned airline miles, was receiving income under a non-accountable plan. The employer would need to report the value of the airline miles as part of the employee's salary. ${ }^{33}$ Due to an outcry

\footnotetext{
${ }^{31}$ Camp, supra note 2, at 27.

32 Joseph M. Dodge, How to Tax Frequent Flyer Bonuses, 48 TAX Notes 1301, 1303 (Sep. 3, 1990).

${ }^{33}$ I.R.S. Tech. Adv. Mem. 1995-47-001 (Nov. 24, 1995).
} 
from the public, the IRS changed its position and ultimately decided not to tax frequent flyer miles unless they were exchanged for cash. ${ }^{34}$

\section{Barter Exchange}

Similar to frequent flyer miles, barter exchanges allowed taxpayers to receive income without a taxable realization event taking place. As discussed above, choosing to leave a job to care for one's child does not create taxable income, but what about a group of mothers getting together to share child caring responsibilities throughout the week? Presumably, each mother is exchanging a service with the other. In the 1960s, barter clubs were created where a doctor would provide a check-up for his contractor who would in turn repair the doctor's house. No money exchanged hands, only the services. Barter clubs reached a stage where they were actually managed systems in which services could be exchanged. ${ }^{35}$

The IRS resolved the barter club problem through guidance that made purely market oriented barter clubs taxable. They imposed reporting requirements on the brokers facilitating these barter clubs. ${ }^{36}$ The doctor in the example above would need to include in income the FMV of the services provided by the contractor. ${ }^{37}$ However, the mothers would not be subject to reporting as long as their exchange has minor economic significance. ${ }^{38}$ So, in addition to property for property exchanges, service for service exchange is also a taxable event.

\footnotetext{
${ }^{34}$ I.R.S. Announcement 2002-18, 2002-1 C.B. 621 (Mar. 11, 2002).

${ }^{35}$ Rev. Rul. 1983-163, 1983-2 C.B. 26.

${ }^{36}$ I.R.C. $\S 6045(\mathrm{c})$ (West 2011).

${ }^{37}$ Rev. Rul. 1979-24, 1979-1 C.B. 60.

${ }^{38}$ MCMAHON ET AL., supra note 25, at $93.03(2)$.
} 


\section{Gambling}

The last unique taxable business that somewhat resembles the structure of virtual worlds, is gambling. Gambling is generally considered a form of entertainment, although there are professional gamblers who do make a living in casinos. The IRS has chosen to treat both amateur and professional gamblers the same by requiring winnings to be included in income and only allowing losses to offset gains from gambling. The logic behind taxing gains, but not allowing losses, is born out of the reason for spending the funds. The money spent on gambling is a non-deductable entertainment expense, but any gain from gambling is a taxable windfall. ${ }^{39}$ The lack of distinction between amateur and professional gamblers is due to the difficulty in distinguishing between the two groups. ${ }^{40}$

\section{Hobby Loss}

In activities outside of gambling, the IRS makes a distinction between those playing for fun and those looking to make a profit. ${ }^{41}$ Section 183 restricts the ability of individuals to take losses for activities that they do not engage in for profit. ${ }^{42}$ The general definition of an "activity engaged in for profit" is one that is not engaged in for sport, hobby, or recreation. There must be objective evidence that the taxpayer entered into the activity or continued the activity with the objective of making a profit. The regulations recognize situations where there is a small likelihood of making a large profit, and will weigh the amount of profit in determining whether deductions for loss will be permitted. ${ }^{43}$

\footnotetext{
${ }^{39}$ Valenti v. Comm'r, 68 T.C.M. (CCH) 483 (1994).

${ }^{40}$ MCMAHON, supra note 25, at $\$ 16.06(5)$.

${ }^{41}$ See Stephen A. Zorn, The Federal Income Tax Treatment of Gambling: Fairness or Obsolete Moralism?, 49 TAX LAW. 1, 35 (2009).

${ }^{42}$ I.R.C. $\S 183$ (a) (West 2011).

${ }^{43}$ Treas. Reg. $\S 1.183-2(a)$ (1972).
} 
There are nine factors applied in determining whether an activity can properly be defined as engaged in for profit. Among them are the manner in which the taxpayer engages, the expertise, the time and effort, the expectation that assets will appreciate, the success in similar activities, history of income with respect to the activity, amount of profits earned, financial status, and elements of personal pleasure. ${ }^{44}$ Section 183 provides a basis for determining whether an activity is a business or a hobby. Many of the factors support treating losses from virtual world activities as non-deductable hobby losses. The real question raised by virtual world players who engage in real world profit generating activities is whether they are actually trying to make a profit, and if so, when they need to recognize that gain.

\section{B. Camp: The Case for a "Cash Out" Rule}

Camp argues that the sales and trades occurring within the online virtual worlds are not gross income as currently defined by the code. Virtual worlds do not create property for the players, but "units of play" that should not be taxed unless converted into a real world form of cash or property. His article examines the fundamental question of when economic gain becomes taxable gain. ${ }^{45}$

The reason for taxing transactions that result in the receipt of real world money (cashing out) is that the transaction is a simple payment for services or property. ${ }^{46}$ Take for example the advanced high-level character that is sold on Google Checkout for $\$ 5,000$. The person who spent the hundreds of hours building up the individual character's skills is simply being paid for the service of developing that character. In Second Life, many of the transactions are easily

\footnotetext{
${ }^{44}$ Treas. Reg. $\S 1.183-2(b)$ (1972).

${ }^{45}$ Camp, supra note 2, at 2-3.

${ }^{46} I d$. at 46.
} 
governed under $\S 1001$ where the individual player develops a virtual product and sells it for a real world profit.

Camp argues that all real money transactions are realizable and taxable events because they can be so closely linked to normal real world transactions. The intent of a person earning income is unimportant and $\S 61$ will recognize the accession to wealth of a taxpayer. The reality is that intent, as in hobby loss provisions, is only important when one wishes to take deductions, not for the inclusion of the income in the first place. ${ }^{47}$

For in-world transactions, Camp discusses how many arguments turn on the importance of ownership in virtual property. If one creates a character in World of Warcraft and develops his skills so that he may fight for and find a sword, the discovery of that sword is not his own property as a result of the terms of service, but remains the property of the game creators. The simple claim is that he does not own the sword legally, (nor can he separate it from the character due to parameters of the software) and therefore, he has not accessed wealth personally. Camp argues that this is still a realization event if one places himself in the shoes of the avatar. ${ }^{48}$ Think of it this way, if one has a job in medieval England as a knight who kills French soldiers, and he obtains the best sword in all the lands, then he is better off. He is accessed to wealth. If he is a player of the game and his sword makes him more powerful, then he is better off and has access to wealth. The problem is conceptual, not legal. In the real world, he is not better off in comparison to his neighbor, but in the virtual world he is better off, and since the item in the virtual world has a real world value, he has access to wealth in both.

The argument that a transaction does not create a realization event further falls apart when one looks at Second Life and the fact that in Second Life, one could immediately exchange

\footnotetext{
${ }^{47} I d$. at 47 .

${ }^{48} I d$. at 58 .
}

PGH. J. TECH. L. \& POL’Y, Vol. 12, No. 2, Fall 2011 
an item for real currency. Second Life has terms of service that grant the player ownership in the property that he produces or buys within the world. ${ }^{49}$ The fact that he owns the property means that if he performs an in-world exchange of one virtual item for another, then there is a realization due to materially different items changing hands. The in-world transaction is just like the transaction in Cottage Savings. ${ }^{50}$

Camp argues that neither Second Life nor World of Warcraft are all that different from each other. The end result is that property one possesses within the world only has value because of the service provided by the company creating the virtual world. This is not a realization question for Camp, but one of imputed income. The individual playing any of these games is actually enjoying property that he owns. The property is a right to continue playing. ${ }^{51}$ The inworld activity is separable from real world activity so that every Linden or piece of virtual loot that one receives is just a "unit of play." A "unit of play" is no different than one entering a casino and receiving the right to use a chip as a unit for gambling. The gambler does not have gross income until he cashes out with the casino. ${ }^{52}$

Recognition of gross income should not occur until the Linden or the virtual good passes outside of the world managed by the game developers. Once the player removes the "unit of play" from the provided service, then there must be recognition. ${ }^{53}$ The consistency of Camp's argument can be seen if it is compared to a barter exchange. In the barter scenario, an exchange of services and goods is taxable unless the exchange is not economically significant, like the mothers trading daycare duties. The barter would only occur if one were trading a virtual good

\footnotetext{
${ }^{49}$ SECOND LIFE, Terms of Service (Dec. 15, 2010), http://secondlife.com/corporate/tos.php (last visited Feb. 16, 2011) (allowing players to retain all intellectual property rights in the content that they create means that as soon as a piece of virtual property is exchanged there is ownership of that property for purposes of realization).

${ }^{50}$ Cottage Sav. Ass'n v. Comm'r, 499 U.S. 554, 566 (1991).

${ }_{51}^{51}$ Camp, supra note 2, at 60

${ }^{52} I d$. at 64.

${ }^{53} I d$. at 69 .
} 
for a real world good. Inside the virtual world, things that look like barters are occurring, but in reality if one takes a step back, one can see that the real barter is between a good or service in the real world for a virtual good or service. ${ }^{54}$ For Camp, the "unit of play" is the piece of property so there is no need to look inside of the virtual world when determining what to tax. Leandra Lederman takes a different position, focusing on the nature of the virtual world and its particular terms of service in determining when property transactions should be taxable.

\section{Lederman: It Depends on Ownership}

Lederman argues that the cash out rule is not a sufficient solution for dealing with the individual that chooses to store substantial amounts of wealth inside of Second Life. ${ }^{55}$ She is concerned with people like Anshe Chung, who is worth one million U.S. dollars in Second Life. ${ }^{56}$ However, Lederman does not argue that all virtual worlds should have taxable internal transactions, but only worlds where the in-world currency can be easily exchanged.

\section{Virtual Worlds that Forbid Exchanges}

In virtual worlds like World of Warcraft, the player is prevented from selling items on third party exchanges. The game administrators achieve their restrictions in two ways. First, they bind items to a particular player, requiring that the player sell the whole account in order to get rid of the item. The second is by banning a player and seizing the player's account if he is caught selling through the exchange. ${ }^{57}$

\footnotetext{
${ }^{54} I d$.

${ }^{55}$ Leandra Lederman, EBay's Second Life: When Should Virtual Earnings Bear Real Taxes?, 118 YALE L.J. PoCKET PART 136, 137 (2009).

${ }^{56}$ Hof, supra note 8.

${ }^{57}$ Lederman, supra note 2, at 1660.
}

PGH. J. TECH. L. \& POL'Y, Vol. 12, No. 2, Fall 2011 
Lederman takes the position that these restrictions make whatever ownership one has in the virtual world, asset illiquid. The lack of liquidity makes it unfair to impose a tax on the individual player. It would be too easy for a player to argue that the in-game income is minimal because there really is no valid way to exchange the internal play for real world currency. ${ }^{58}$

\section{Exchange Worlds}

Exchange worlds are games that resemble Second Life. They are online marketplaces where one can buy and sell goods as well as provide services in exchange for an internal currency. The key to these worlds is the fact that in-game currency can be traded for real currency, and the trade itself is actually encouraged by the game developers.

Lederman sees the free exchange as making a liquid online market. The fact that Second Life is "intentionally designed" as a platform for commerce makes it more like a barter exchange. Just as with barters, the avoidance of taxation can occur when one stores revenue in the form of Lindens. ${ }^{59}$ Even the exchange of property should be taxable because the virtual sword is materially different from the virtual rock and under Cottage Savings that exchange is taxable. ${ }^{60}$ Lederman argues that one can separate out the design of virtual worlds, and therefore can make a principled argument for taxing some and not others.

\section{Lederman is Technically Correct.}

Lederman essentially concludes that when a player earns or obtains Lindens he is accessing wealth and therefore has income. Her conclusion, based on the tax law as it stands now, is correct. A comparison of Second Life to the world of gambling highlights the point that

\footnotetext{
${ }^{58} I d$. at 1661 .

${ }^{59} \mathrm{Id}$. at 1666 .

${ }^{60} I d$. at 1653 .
} 
any person currently playing the game and ending the year with net gains in Lindens, has income that should properly be reported.

\section{A. How Gambling Parallels Second Life}

The Linden dollar is traded on an open exchange. It has a floating rate, but that is only because the game developers have developed the system that way. What if the Linden dollar looked more like a casino chip? Instead of creating a floating rate, why not set the system so that there are four different Lindens: gold, silver, bronze, and copper. Each Linden has a real world value of 15, 10, 5, and 1 real world dollars respectively. The player could purchase each type of Linden at the specified price and sell it for the same specified price. The LindeX could permit these types of exchanges between players, but the rate would be fixed. The Linden then becomes nothing more than a casino chip.

In a casino, one can enter the casino, but must exchange cash for chips before being permitted to participate in the different games. Similarly, Linden Labs prohibits one from "participating," or buying items, without exchanging real world money for their form of chips. The chips are not property in the hands of the gambler, but are actually property of the casino in all contexts. $^{61}$ The chip itself is just a mechanism of accounting for the casino. It is not even property in the hands of the player, but rather a mechanism that represents real world currency and allows the player to participate. At the end of the year, the player (assuming the player is using the cash method) must account for all of his winnings and losses regardless of whether they are chips or cash. Camp does forward an example of not accounting for individual wins and

\footnotetext{
${ }^{61}$ Zarin v. Comm'r, 916 F.2d 110, 114 (3d cir. 1990).
} 
losses in each game, however, he is referring to the wins and losses of a particular game (e.g., hands during a poker game) not a day of playing. ${ }^{62}$

Assuming a player does not report his winnings at the end of the year, the IRS, on audit, will reconstruct those winnings. Each player receives a card and registers his name, address and date of birth when exchanging cash for chips. This allows the casino to internally track each individual player's bets, wins, losses, and "comps." If the IRS audits the player, on subpoena, the casino will turn over records of each day's transactions. Essentially, the casino keeps track of all the winnings and losses of the player for each day. The concept of converting winnings from chips to cash is irrelevant. ${ }^{63}$ The IRS only looks to see whether a player has winnings from a taxable year (obviously they permit losses to offset winnings). ${ }^{64}$ As a result, a player that cashes out is treated no differently than the player that takes his chips and stores them in a safe deposit box.

\section{B. What Does This Mean for Second Life Players?}

The Second Life world is perfectly analogous to the gambling scenario. Essentially, the player is exchanging his cash for chips (Lindens) and the chips increase or decrease through game play. Just like in gambling, the player does not own the Lindens in his or her account - the game developers maintain a right to the Lindens and use them like an accounting mechanism. ${ }^{65}$

\footnotetext{
${ }^{62}$ See Camp, supra note 2, at 64 (discussing the taxation of gambling winnings when the chips are exchanged for cash). One does wonder what the IRS might argue on audit if a gambler, playing one game of Poker, won $\$ 100,000$ (in chips) before $12: 59 \mathrm{pm}$ on December $31^{\text {st }}$, and then subsequently lost it all before the individual game was complete. Would the first $\$ 100 \mathrm{k}$ be taxable gambling winnings for year 1 , and the other $\$ 100 \mathrm{k}$ is losses in year 2 for which the gambler has no offsetting winnings?

${ }^{63}$ See generally Barbiero v. Comm'r, T.C. Memo 1992-381 (1992) (demonstrating how the IRS reconstructs winnings of a taxpayer from casino records).

${ }^{64}$ See McClanahan v. U.S., 292 F.2d 630, 631 (5th Cir. 1961) (discussing the need to report gambling winnings regardless of whether one has lost more than they have one in a particular year).

${ }_{65}$ See generally id; SECOND LIFE, Terms of Service (Dec. 15, 2010), http://secondlife.com/corporate/tos.php (barring ownership of the Linden's by individual players). Second Life makes money by charging real dollars on different
} 
The actions that a player takes should be treated as gambling expenses. Just because the game does not involve the spinning of a roulette wheel or the shuffling of cards does not make the process at its core any different from a gambling transaction.

If a player has income every time a Linden is made in Second Life then the player should be reporting the income to the IRS. The player can account for the amount of money placed into the game by keeping a record of U.S. dollars transferred from his PayPal account. Then they can perform an accounting on the last day of the year that includes all the Lindens, the FMV of any virtual property and any cash already pulled out of the game. Following a very strict interpretation of income leads to the conclusion that under current law, a taxpayer must account for gains in virtual wealth on his tax return. However, requiring accounting for property in the game environment does not provide a proper reflection of whether someone who is playing a game should be taxed just like someone attempting to run a for profit business within the game.

\section{Taxation at the Cash Out, and Be Creative}

While Camp's conclusion may not reflect the code's definition of income, as it exists today, it does provide a better method of taxing the type of taxpayer playing in a virtual world. Camp's conclusion provides easier and better treatment of taxation for virtual worlds, but just like Lederman, he becomes too embroiled in the nature of virtual worlds. If one takes a step back and looks at the reality of what taxation means in the virtual world, Camp's conclusion becomes inevitable. This section takes that step back, and proposes ways in which the IRS could enforce taxation when a player cashes out, essentially exempting players from having to report until actual cash out occurs.

transactions like the exchange of Lindens. By maintaining property rights in the Linden's, Second Life is able to control the supply of the currency, similar to the Federal Reserve. 


\section{A. Why Cashing Out Should be Necessary to Create Realization}

I propose three reasons why the IRS should use the cash out rule to deal with income earned in virtual world transactions. First, looking too far into the virtual world creates infinitely complex tax questions that cannot be dealt with administratively. Second, the virtual world is not the real world in many ways, and accession to virtual wealth is not the same as real world wealth. Third, the IRS chooses what to tax and how to tax for reasons that are not as intellectually true as authors of law review articles may prefer.

\section{What is Really Happening in Second Life?}

Under Lederman's analysis we must tax the in-world transactions between players. Looking at Terry's activity from the beginning of the article, there are two distinct incomeearning activities: sale of property and personal services. As discussed earlier, the entire game play can be analogized to gambling, but some of the virtual interactions appear to reflect entirely different concepts. The sale of intellectual property is easy to deal with, in fact, if one wished, he could properly account for all the costs that go into the development and sale of the property. ${ }^{66}$ The personal service of a security guard for instance is not a sale of property, it is a lease or it is an actual form of employment.

Starting with the lease analogy, one would have to see the security guard (sg avatar) as a piece of property that the player is renting out to another player. ${ }^{67}$ The ability of one player to use another player's avatar to perform a service or action is similar to renting a security camera. The owner of the camera receives a stream of lease payments while the camera performs the

\footnotetext{
${ }^{66}$ See DIBBELL, supra note 11, at 245 (providing a snapshot of the "Ultima market" for a particular week based off a program that scans all sales on eBay, and develops a fair market value of both property and gold pieces).

${ }^{67}$ Camp, supra note 2, at 60 (arguing that the activity is not a market transaction but a self-provided service).
} 
necessary service. The difference however, is that the player needs to be monitoring the sg avatar in order for the avatar to function.

The sg avatar may resemble more closely the individual watching the security camera than the camera itself. If the player is sitting at his computer operating the avatar and speaking to other players then it is not much different than some modern security guard jobs. Sitting in front of a computer screen watching the monitors and buzzing people into a building through an intercom is not conceptually different from the person playing Second Life. This raises the question of whether payroll taxes need to be collected for these services either by the employer or accounted for by the independent contractor. ${ }^{68}$ This would be impossible to enforce and would never be followed by any of the players. The IRS could argue that the income is simply not a wage and therefore not subject to employment tax. However, as discussed infra, if the players start performing tasks that involve examining cancer scans the activity looks like something that the real world would call a wage.

Lederman's analysis leads to these types of problems because she views the Second Life world as a barter-exchange where real world services and property are involved. It appears on its face that virtual property and currency, because it has real world value, should be treated like intangible property. However, if one takes a single step back, it is obvious that neither the currency nor the property are the same as in the real world, and while there is income, the IRS should exempt that income.

\section{The Step Back}

Camp makes the argument that taxation should not occur until one cashes out because the real piece of property is the account. When one buys property and sells it within the virtual

\footnotetext{
${ }^{68}$ See I.R.C. $§ 3402$ (2010) (requiring employers to withhold income tax at its source).
} 
world, it is similar to holding a stock that increases and decreases in value and realization does not occur until stock is disposed of through sale or some other means. ${ }^{69}$ There is a fairness argument about why one does not tax stock through mark to market, and a similar argument exists for virtual world income. ${ }^{70}$ The reasons can be seen in both the nature of the wealth that one earns in virtual worlds, and the nature of the person that plays the virtual game.

If I trade a super sword for a cloak of invisibility, I have exchanged materially different items within the virtual world as well as in the real world because as I play the game I am able to do different things with each piece of property. But what have I actually gained? In Second Life, I have a piece of code created by shaping a "primitive" using a program owned by Linden Labs. The piece of code looks like an object only because Linden Lab provides the necessary service. However, the object and its actions are of no value without the service provided by Linden Labs. The reality is that the only value I have in the particular item is due to the service that is provided. ${ }^{71}$ The item does not exist independent of the virtual world.

When I trade a service such as will drafting for a service from my carpenter, we each receive something whose existence is independent of a third party. In the case of virtual worlds, the accession to wealth only exists due to the platform provided by the game developers. Even intangible property in general has an existence separate and apart from a third party, because a computer program is internally capable of existing even if Microsoft decides that they will not make Windows any longer. ${ }^{72}$ While the accession to wealth requires that one have something

\footnotetext{
${ }^{69}$ See I.R.C. $§ 1001$ (2010) (defining the calculations necessary for determining recognition at the time of sale).

${ }^{70}$ See I.R.C. § 1256(b)(2) (2010) (requiring only securities dealers with futures contracts mark the contracts to market at the close of the taxable year).

${ }^{71}$ This premise alone does not mean there is no value in the item, but combined with additional factors, it looks less like property ownership and more like service use rights.

${ }^{72}$ SECOND LIFE, Terms of Service (Dec. 15, 2010), http://secondlife.com/corporate/tos.php, (last visited Feb. 16, 2011).
} 
that they did not have before, the reality is that the player in a virtual world has use of a service before they exchange an item and they have the same use of that service after the fact. ${ }^{73}$

Lederman argues the fairness aspect of taxing before cash is received by examining the individual player. She makes a compelling argument that any tax on loot drops, a World of Warcraft like scenario where one slays an imaginary creature to receive an item that is not readily exchangeable for real world currency, is regressive because the individual playing the game is most likely a person with less real world wealth. ${ }^{74}$ Therein lies the rub, Lederman argues that taxation of Second Life worlds would not be regressive because of the readily exchangeable nature of the property and currency within the world, but the reality is a tax on inworld Second Life transactions would be just as regressive. A Second Life tax would be just as regressive because of the nature of the game play. In order to learn the game, a player must spend twenty hours just getting acquainted with the controls and the basics. ${ }^{75}$ In order to start generating revenue that is more than de minimis in the real world, a player needs to keep a large amount of capital within the virtual world. ${ }^{76}$ A tax on virtual world income would be regressive because the individual playing the game must have large amounts of leisure time and must spend it playing the game. ${ }^{77}$ What the regression analysis admits to is the fact that we do not value

\footnotetext{
${ }^{73}$ Commissioner v. Glenshaw Glass Co., 348 U.S. 426, 431 (1955) (holding that accession is clear when the taxpayer has complete dominion over the property obtained).

${ }^{74}$ Lederman, supra note 2, at 1659.

${ }^{75}$ Mitch Wagner, Second-Day Thoughts on the New Second Life Viewer, COMPUTERWORLD, (Feb. 24, 2010, 1:43 PM), http://blogs.computerworld.com/15649/second_day_thoughts_on_the_new_second_life_viewer (last visited Feb 22, 2011).

76 Linden Research, Inc., Getting Linden Dollars FAQ, SECOND LIFE (Nov. 29, 2009), http://wiki.secondlife.com/wiki/Getting_Linden_Dollars_FAQ (discussing that a person needs to put significant investment into the virtual world in order to produce a decent return. Think about this as more than just a stock investment, but an infrastructure investment. The storefront will not be sold, but it costs a lot in the micro-economy to get it built in a good location).

77 See generally George K. Yin, Accommodating the "Low-Income" in a Cash-Flow or Consumed Income Tax World, 2 FLA. TAX REV. 445, 459 (discussing a cash flow tax while displaying some very helpful examples of how those with less ability to save end up paying more in consumption tax than those with greater means).
} 
virtual wealth the same as we value real wealth. The college kid in his parents' basement may have the greatest nightclub in Second Life, but he still needs his mother to give him gas money.

In addition to the nature of the player is the nature of the play itself. Users admit to being unsure of whether they are playing to make money or they are playing for fun. ${ }^{78}$ The question is: Would I still play if I did not make $\$ 3,000$ a month? This could be the biggest reason for only taxing when a player cashes out. At the end of the day it is still a game. In fact, many players who make money within the virtual world also maintain virtual world businesses and activities that would never exist if it weren't for the fact that the virtual economy is on a micro scale. It is very easy for the IRS to identify a business operated for profit if it costs someone $\$ 100,000$ a year to maintain, but if someone puts $\$ 40$ a year into a virtual world to maintain a store that sells tee-shirts is that really an activity operated for profit? At the end of the day the IRS sometimes overlooks all of the academic arguments that try to fit particular types of income into predetermined categories, and just taxes in a way that is as administratively easy.

\section{Taxing at cash out because we can}

There are a plethora of examples where the IRS ignores actual income according to the definitions of realization and accession to wealth, and chooses to tax only when real cash is in the hands of the taxpayer. Some of the best examples of this are installment sales, mark to market, and frequent flyer miles. The IRS should choose to apply similar standards to the taxation of virtual worlds.

Installment sales and mark to market transactions involve increases in wealth that are not taxed because the individual taxpayer has not realized, in the form of a receipt of cash, that

\footnotetext{
${ }^{78}$ See DiBBELL, supra note 11, at 297 (discussing the fact that his work was done not for the money but for the play associated with it).
} 
would allow them to pay an imposed tax. ${ }^{79}$ Lederman argues that Second Life is a world in which one could easily sell his property to obtain the cash necessary to pay any tax. ${ }^{80}$ However, the tax system recognizes that this is not always an ideal solution and permits a deferral until actual cash is received. In installment sales, it means that the taxpayer does not have to sell their note at a discount to a bank (something not available for Second Life players) ${ }^{81}$ In the case of Second Life, not taxing until actual cash is received would represent an understanding that the value of the property received may be part of the game play and not part of the realization of taxable income. The debate that the IRS engaged in with airline miles provides an even stronger example of treating particular situations differently.

An IRS agent probably put it best when asked about the involvement of the IRS in taxing virtual worlds: "See if it'll buy you a beer. Well, it can. But to me it can't. And to the government it can't — yet ... And as soon as it starts holding value, you're gonna wish it didn't $\ldots{ }^{82,}$ The problem with taxing the in-world transaction, no matter how much the in-world transaction appears to be a realization event, is that the virtual world itself could be easily destroyed. If most people are playing a game, the need to file a tax return at the end of the year will make them stop playing. ${ }^{83}$ While there is significant revenue generated within the virtual world and technology does exist to deal with the administration, the IRS should choose not to tax the transactions for similar reasons it "chooses" not to tax airline miles.

\footnotetext{
${ }^{79}$ David F. Shores, Closing the Open Transaction Loophole: Mandatory Installment Reporting, 10 VA. TAX REV. 311, 312 (1990).

${ }^{80}$ Lederman, supra note 2, at 1666.

${ }^{81}$ See Shores, supra note 79, at 320 (arguing that the installment sale has outlived its purpose because financial markets allow the taxpayer to convert installment obligations into cash).

${ }^{82}$ DIBBELL, supra note 11, at 307.

${ }^{83}$ This may not be true for the individual attempting to run a virtual business, but the casual player, the one generating the revenues for a the virtual business owner, would turn to the game that did not have the IRS administrative paperwork.
} 
As discussed earlier, the IRS went from proposed regulations for taxing airline miles earned through business travel to regulations that guarantee the IRS will not tax airline miles. ${ }^{84}$ Airline miles could have been taxed very easily. There were multiple ways of achieving that end which would have gotten at the accession to wealth, which resulted from the receipt of the miles. $^{85}$ In spite of strong reasoned arguments to the contrary, the IRS ultimately chose not to tax airline miles unless they were exchanged for cash. ${ }^{86}$ The IRS should make a similar decision with regard to in-world transactions. Complications that range from valuation, to the effect that taxation would have on a micro-economy, to the inability to determine if someone is playing for profit, make the cash out rule the most consistent way of taxing the person actually realizing and recognizing something that is valued in the real world.

Under current regulations, a taxpayer with Second Life Lindens could be required to account for those Lindens on his tax return as income. ${ }^{87}$ The IRS can and should issue a revenue ruling or announcement similar to the one issued for frequent flyer miles. ${ }^{88}$ The IRS should state that they will not assert an understatement of tax liability on a taxpayer with virtual world gains. The key will be to set parameters so that "virtual world games" are clearly defined and can be differentiated from online money transfers, banks and auction sites like eBay. In addition, they should clarify that this rule applies only to straight in-world transactions. The minute real world currency becomes involved, like when frequent flier miles are converted to cash, the taxpayer

\footnotetext{
${ }^{84}$ See generally Darrell L. Oliveira, The Taxability of Frequent Flyer Credits Earned by Employees: Why the IRS has Remained Silent on the Issue, 4 U. PA. J. LAB. \& EMP. L. 643, 648 (2002) (discussing some of the very same problems of realization, valuation, and severability that exist in virtual worlds as problems that plague the frequent flyer system).

${ }^{85}$ Compare Dodge, supra note 32, at 1303 (proposing that the IRS tax airline miles when they are redeemed for a ticket at the FMV of the ticket at that time), with I.R.S. Tech. Adv. Mem. 95-47-001 (Nov. 24, 1995) (proposing that the employer include the value of the miles at the time they are earned by the employee meaning they would be taxed whether utilized or not).

${ }^{86}$ I.R.S. Announcement 2002-18, 2002-1 C.B. 621.

${ }^{87}$ Compare I.R.C. $§ 1402$ (2010) (requiring the reporting of net earnings less deductions, however, this might conflict with hobby loss rules), with I.R.C. $\S 1221$ (2010) (not differentiating between virtual and real property, which would presumably include a Second Life building in the definition of capital asset).

${ }^{88}$ I.R.S. Announcement 2002-18, 2002-1 C.B. 621.
} 
has a reportable transaction. The IRS has taken some steps to police online sales. The new reporting requirement for transaction facilitators is a way of enforcing the cash out rule.

\section{B. Reporting Requirements $\S 6050 \mathrm{~W}$ and Form $1099-\mathrm{K}$}

Starting in the 2011 tax year, the IRS will begin implementation of a new reporting requirement designed to make auditing and compliance of online merchants easier. Any individual selling over $\$ 20,000$ and engaging in over 200 transactions will have their gross revenue reported to the IRS by the third party settlement organization. ${ }^{89}$ This section will first examine the new regulations and how they will ensure reporting of virtual world cashing out events, and then will also propose an idea for how the IRS could incentivize the payment of taxes within the virtual world.

\section{Third Party Settlement Organizations}

In the past, the way to wire money was through Western Union. PayPal was founded in 1998 as a way of providing Western Union like services to individuals selling products on the Internet. PayPal was a solution to a problem that had not become that large yet. Online auction sites like eBay facilitated the sale between two private parties (P2P) like online classifieds. The problem was that the seller was unable to accept a credit card as payment. The buyer would be forced to mail a check to the seller and the seller would wait for the check to clear before sending the goods. PayPal allows these P2P transactions to occur with credit cards instantly rather than with mailed checks. ${ }^{90}$ PayPal, however, is not a bank; it is closer to a Western Union like system

\footnotetext{
${ }^{89} \$ 20,000$ is a relatively large threshold, and the player who does not want to fall under the reporting rule could wait till the end of the year to convert Lindens to dollars. Therefore, they would never exceed the 200 -transaction rule. See I.R.C. $§ 6050 \mathrm{~W}$ regarding third-party settlement organization.

${ }^{90}$ Ronald J. Mann, Regulating Internet Payment Intermediaries, 82 TEX. L. REV. 681, 683 (2004).
} 
of money transfers. The system was largely unregulated both in IRS reporting, banking fraud and money laundering provisions. ${ }^{91}$

The IRS has addressed the lack of reporting for PayPal like systems with the implementation of $\S 6050 \mathrm{~W} .{ }^{92}$ PayPal is really the main way in which players of any virtual world can obtain real world currency for the sale of their virtual currency. The over-arching problem facing the taxation of virtual worlds, even at the cash-out stage, was that there existed no reporting of the cash out transaction. ${ }^{93}$ So even if a player cashed out of the game, they would not be taxed unless they self-reported that income at the end of the year.

The implementation of $\S 6050 \mathrm{~W}$ is estimated to raise $\$ 9.5$ billion over the next ten years. ${ }^{94}$ Instead of targeting a company like eBay or Linden Labs, the IRS has targeted the transaction site that allows real world money to be obtained in exchange for real or virtual property. What will happen is a "third party settlement organization," PayPal, must report to the IRS all individuals who receive $\$ 20,000$ or more in "payments" and whose number of transactions exceeds $200 .^{95}$ The third party settlement organization will then mail a $1099-\mathrm{K}$ to the respective taxpayer listing the gross value of transactions for each month during the taxable year. ${ }^{96}$ The implementation of this reporting system will ensure better compliance amongst individuals earning income through virtual world transactions. Tax returns will be flagged if there is an

\footnotetext{
${ }^{91}$ See id. at 691 (discussing how both banking privacy rules and electronic fund transfer laws fail to actually apply to $\mathrm{P} 2 \mathrm{P}$ systems).

${ }_{92}^{92}$ I.R.C. $\S 6050 \mathrm{~W}$ (2010) (requiring reporting by third party settlement organizations like PayPal).

${ }^{93}$ See Maricel P. Montano, Can Widening the Scope of Information Reporting to Include Income Derived From Online Sales Help to Narrow the Expanding Tax Gap?, 83 S. CAL. L. Rev. 379, 391 (2010) (discussing the asymmetrical reporting regime create by placing the entire onus upon the taxpayer to report any income from online sales).

${ }^{94}$ See Joint Comm. on Taxation, 110th Cong., Estimated Budget Effects of the Tax Provisions Contained in H.R. 3221, The "Housing and Economic Recovery Act of 2008," Scheduled for Consideration by the House of Representatives on July 23, 2008, at 3 (Comm. Print 2008), available at http://www.jct.gov/publications.html?func $=$ startdown\&id $=1275$.

${ }^{95}$ I.R.C. $\S 6050 \mathrm{~W}(\mathrm{e})(2010)$.

${ }^{96}$ See IRS, http://www.irs.gov/pub/irs-dft/f1099k--dft.pdf (last visited Feb. 22, 2011).
} 
independent report from a payment site listing individual taxpayer transactions. ${ }^{97}$ In addition targeting large "payments" and large numbers of transactions means that the smaller "player" will not be swept up in an overly burdensome regulatory system that might deter him from even playing in the virtual worlds.

\section{a. The Taxpayer Who Stores Wealth in Virtual Worlds}

Section $6050 \mathrm{~W}$ also addresses the problem of taxpayers that store wealth inside of virtual worlds. Lederman argues that the receipt of a Linden in Second Life should be taxable because it is the equivalent of the receipt of cash. She states that if one is only taxed when Lindens are used to purchase real world goods there would be an inconsistent tax on purchases rather than sales. ${ }^{98}$ What should really happen is that Lindens should not be taxed as long as they are not used for real world purchases because they cannot be used for real world purchases. Instead of looking at the purchases, look at the system. As the IRS agent put it, "See if it'll buy you a beer. ${ }^{99 "}$ If the Linden becomes a different name for the dollar then Second Life will start to look like a "third party settlement organization."

Companies like Linden Labs want to facilitate game play, and that does not involve facilitating payments for goods and services. The definition of a "third party payment network" is one that establishes accounts through contract for unrelated parties, provides a standard mechanism for settling the transactions, and guarantees the payment to the person providing the service. ${ }^{100}$ Second Life makes no such payment guarantees, but allows a largely unregulated world to exist in which people use the Lindens for in-world services and goods. If someone

\footnotetext{
${ }^{97}$ See Montano, supra note 93, at 412 (discussing the importance of $6050 \mathrm{~W}$ in closing the tax gap by breading a culture of compliance in a world where no compliance was necessary).

${ }^{98}$ Lederman, supra note 55, at 140.

${ }^{99}$ DiBBELL, supra note 11 , at 307.

${ }^{100}$ Treas. Reg. § 1.6050W-1(c)(3) (2010).
} 
agreed independently to sell a beer for Lindens there would be no guarantee of payment. However, that transaction would be no different than an illegal offshore money laundering activity.

Section 6050W ensures that Second Life and similar virtual games will keep the economic transactions virtual. If the game designers slip too far into real world transactions their systems look less like game accounts where players invest capital into the experience, and more like third party payment networks where taxpayers are storing assets like they have an online bank account. A game designer may be less inclined to fall under the $\S 6050 \mathrm{~W}$ requirements because they would be forced to collect taxpayer identification numbers for players as well as monitor every transaction that occurs within the system.

\section{b. Focusing on Payment Systems is a More Sustainable Approach}

The IRS wants to be able to establish a system that addresses individual taxpayers earning a living through online sales. If I sell huge quantities of eBay items to the point where it no longer looks like a garage sale, the IRS wants to tax the profit that I earn on those sales. Up until this past January there was no reporting requirement that would flag sales in an audit. By focusing on PayPal-like systems, not only will eBay sales be flagged, but so will all other online sales. There may still need to be adjustments made to the quantity of transactions. Because of the nature of a Linden for dollar exchange, the number of transactions can be kept low, and therefore avoid the reporting requirement.

Second Life may be on its way out as a popular virtual world. ${ }^{101}$ Since the IRS has focused on third party payment networks it does not matter whether Second Life disappears or

${ }^{101}$ See Mitch Wagner, Second Life CEO looks to the future after Massive Layoffs, COMPUTERWORLD (June 11, 2010, 12:16 AM), http://blogs.computerworld.com/16303/second_life_layoffs (last visited March 2, 2011) 
not. When a new game comes in to take its place, like Facebook's recent foray into addictive virtual games, ${ }^{102}$ there is no need to do an evaluation of the virtual transactions that occur because the payments will still be going through the third party systems.

\section{A Creative Solution for Taxing In-Game Transactions}

One would think that a successful virtual world would give someone complete freedom, however games have failed because they allowed too much freedom. It is almost like trying to solve a Sudoku puzzle that has all the blocks filled in but one. Virtual worlds, especially those like Second Life, where users design a large portion of the environment, thrive on the player's satisfaction in being creative. If it were too easy, if everything were there already, there would be no puzzle to solve, and therefore no satisfaction. ${ }^{103}$

Scott Adams recently asked the readers of the Wall Street Journal to propose creative ways to incentivize the rich to pay taxes. ${ }^{104} \mathrm{He}$ argued that politicians that want to tax more have been getting it wrong by merely berating and threatening taxpayers into paying more. He asked for creative solutions that give the rich something they value, time. One of his examples was

(reporting on 300 layoffs by Linden Labs, and what appears to have been the peek of Second Life's user base). Mr. Wagner argues that Second Life suffered from user difficulty because you needed to download a program and spend twenty hours learning how to play. While virtual worlds never really disappear they tend to peak and then exists for many years with a small contingent of dedicated players. Id.

${ }^{102}$ Nick Wingfield and Anupreeta Das, Zynga Is Close to Raising as Much as $\$ 500$ Million, WALl ST. J., Feb. 19 , 2011, at B2 (reporting that Zynga a game company that operates through Facebook may be valued at almost $\$ 10$ billion). Zynga is the creator of games like Farmville where the Facebook user is encouraged to play the game because his or her Facebook friends play the game. In order to get players to actually spend money on it offers to purchase items and improve one's skills are made in the context of giving gifts or prizes to one's friends. Id. See also Geoffrey A. Fowler and Nick Wingfield, Facebook to Make 'Credits' Mandatory for Games, WALL ST. J., Jan. 25, 2011, at B5 (reporting that Facebook will require all games played on their site to use Facebook Credits, a unit of currency used on Facebook, but not exchangeable between Facebook users like the Linden). Facebook credits function in a way similar to Lindens, however the purchaser must use cash to purchase the credit from Facebook. Then the credit can be exchanged, but only to purchase virtual goods sold by Facebook and its subsidiaries like the game creator Zynga. The credits are more analogous to Disney Dollars in that the only transaction that really takes place is when the player pays real world dollars to Facebook. Id.

${ }^{103}$ DIBBELL, supra note 11, at 296.

${ }^{104}$ Scott Adams, How to Tax the Rich, WALL ST. J., Jan. 30, 2011, at D1 (proposing ideas like giving the highest tax bracket the ability to drive in the HOV lane with only one person in the car, or giving them an extra electoral vote). 
government agencies like the DMV agreeing to create a special line for those in the top tax bracket. ${ }^{105}$ My creative idea for virtual worlds is to create an in-world IRS office, and tax day.

The IRS could easily incentivize the payment of taxes in Second Life by creating a tax agency in the world. Part of the "game play" could be to complete a tax return on a certain day, and hand it into the IRS office. In return, the IRS could reward the player with a small in-world token that is unique to that player. The more you pay and report, the bigger the prize. The prizes are just simple codes that could be built at minimal expense. In fact, it would create an entire inworld industry around preparing and filing returns similar to the one we have in the real world. There are already special tax return preparer buildings for sale in Second Life. ${ }^{106}$ This is not as far off a concept as one might think. There have been proposals to build into games the task of reviewing diagnostic scans for cancer as a way of leveling up a character. The thought is that most of these cancer scans are outsourced to India, and that game players might actually do a better job because of the importance of their success in the game. ${ }^{107}$

\section{Conclusion}

The IRS has addressed the problem of virtual worlds in the correct way. Instead of worrying about whether one has recognized income or whether they have implied income until the time that cash is received, they have decided to focus on the facilitators of virtual wealth. They still must ensure that virtual wealth itself is not taxable until cash out through a revenue ruling or administrative pronouncement. If such an adjustment is not made, there is nothing stopping an agent from requiring a taxpayer, on audit, to include the amount of gain contained in

\footnotetext{
${ }^{105} I d$.

106 SECOND LIFE, https://marketplace.secondlife.com/p/Infinite-Possibilities-Cube-Linden-Tax-Services-OfficeFULLY-FURNISHED/1268795?id=1268795\&slug=Infinite-Possibilities-Cube-Linden-Tax-Services-OfficeFULLY-FURNISHED (last visited Feb. 22, 2011).

${ }^{107}$ See DIBBELL, supra note 11, at 295 (discussing the way play and work have become one in virtual environments).
} 
the virtual world. Section $6050 \mathrm{~W}$ targets the third party settlement organizations, which are the real source of value in virtual property. If it required the mailing of checks in order to transfer virtual items, the market wouldn't exist. By targeting large users of systems like PayPal the individuals making a living through significant transaction in virtual worlds can be properly taxed. 